\title{
Remembering James G. March, Ambiguity and the Art of Leadership
}

Dear Editor-in-Chief,

The first time we met Professor James G. March in person was at the Stanford University Workshop on 'Ambiguity and Decision-Making in Chinese Organizations' from January 20-21, 2012 at the Knight Management Center, Stanford University. He not only actively listened to every speakers' presentations during the two-day workshop, but also probed interesting questions in guiding us intellectually to think, reflect, and debate the meaning of ambiguity in the context of Chinese organizations, vividly demonstrating a scholar's quest (March, 2018). We were privileged to have a scholar of such high esteem spend two full days with the entire workshop. The focal puzzle in the workshop concentrated on how and to what extent would cultural, social, political, and historical contexts in China influence the manifestations of ambiguity, individual decision-making and organizational behaviors?

After the ambiguity workshop, Professor March invited us to his office. We discovered his sense of humor, humility, and accessibility through a close person-to-person interaction and open dialogue with him. We gathered up our courage and proposed our little idea of researching poetry and ambiguity. Professor March warmly encouraged us to explore this little idea. He showed us the poems he himself composed and shared his understandings of the commonality among poetry, leadership, and managing organizations (March, 2006). He never suggested a definite direction to do research but voiced various questions to guide our thinking. We clearly remember Professor March's guiding questions, such as 'What are the contemporary implications of poetry for organizations and society today? How was gender expressed in Chinese poetry'? This once-ina-lifetime workshop and our personal meeting with Professor March planted the seed for our MOR paper on poetry, leadership, and ambiguity (Xing \& Liu, 2015).

The MOR Special Issue Call for Papers on 'Ambiguity and Decision-Making in Chinese Organizations and Thought' was publicized shortly after the Stanford Workshop. This exciting special issue was to be edited by Mie Augier, James G. March, Mooweon Rhee, and Xueguang Zhou. Despite the fact that our little idea was out of the main stream research in management and organization 
studies, we submitted the paper with the hope to challenge the status quo by proposing an unconventional idea. Eventually, the special issue did not come to fruition. However, our poetry paper was the only one that survived the review process. When connecting the dots backward, we truly agree with Professor March that ambiguity is an important and powerful concept in organizations and for organizing witfully, especially manifested in his late writing in appreciating 'ambiguity as source of intelligence' (March, 2010). However, empirical examination of ambiguity is hard to perform. We are very lucky to encounter Chinese poetry embedded with ambiguity. Poetry has a profound and lasting impact on Chinese society, in the past and today, with deep cultural and intellectual roots. The Stanford conversation with Professor March inspired us to explore the connection between poetry and leadership in China with the attempt to articulate the meaning of ambiguity.

After final acceptance of the poetry paper, we sent it to Professor March and thanked him with all our heart for the enlightening conversation at Stanford. To our great surprise and encouragement, he responded promptly by email and commented 'I enjoyed reading it and feel it is an important contribution to my own understanding. I hope you continue your research in this direction'.

During our conversation with Professor March, he noted that great leaders, oftentimes, are great poets who have rich and deep feelings to inspire others, because they have compelling power to attract people to contemplate the beauties of life. This beauty of life is intrinsic and philosophical, and therefore needs to be explored and realized. Great leaders are good at inspiring others, because they are more adept at discovering various possibilities of things, and thus better at contemplating the beauties and value of life, consequently, to inspire others with limitless creativity. Their deep feeling can be triggered by what is implied in great leaders' finite words with infinite meaning.

Emperor Cao Cao of Wei Kingdom is widely acknowledged to be a great leader as well as a great poet. His most famous poem, 'come to view the boundless ocean, from Stony Hill on eastern shore; Its water rolls in rhythmic motion, and islands stand amid its roar; The sun by day, the moon by night, appear to rise up from the deep; the Milky Way with stars so bright, sinks down into the sea in sleep; How happy I feel at this sight! I croon this poem in delight' made use of dynamics and statics to integrate the scenery in sight harmoniously with his lofty aspiration to make great ambition. On arriving in Qinhuang Island, Chairman Mao thought of this poet at first when facing the boundless sea, and then made the exclamation 'dating back to thousand years ago, the emperor of Wei Kingdom left over the imperishable poet when facing the eastern shore, while it is a totally different world on the bleak autumn today'. We believe that this embodies Professor James G. March's argument that 'Leadership involves plumbing as well as poetry' (Coutu, 2006). Great poetry casts reflection on the process where the limited lifetime interacts with limitlessness, and transcending limitation into limitlessness is the integration of emotion and scenery, human and nature. From this perspective, great leadership resorts to emotional other than rational 
persuasion or communication, with the main purpose to affect readers mentally instead of reasonably. In other words, Professor March believed that poetry relates to human sentiments and establishes an integration of sense and reason.

To our complete surprise, our poetry and leadership paper received the Inaugural Hermann and Marianne Straniak Stiftung - MOR Best Paper Award at the 2016 IACMR Hangzhou Conference. This surprising award delighted us to cherish the deep insights and thoughts Professor March developed and the similarity to some classic Chinese philosophers and thinkers (Rhee, 2010). As a scholar's scholar and thought leader in management and organization studies, Professor March had a sharp eye to discern the diverse phenomena on the surface, and the will to dig deeper into the core questions with theoretical elaborations that transcend across time and space. It was his broad brush ideas that define the Behavioral Theory of the Firm (Cyert \& March, 1963), his appreciation of the beauty of mathematical models in social sciences (Lave \& March, 1975), his sense and sensitivity, emotionally embedded in poetic collections (March, 1980, 2000), a true role model as a management scholar, and more ... that we will remember and cherish forever.

Our acquaintance with Professor March encouraged us to travel a road less travelled, quite uncertain and ambiguous, unpredictable, yet rewarding with surprisingly intellectual stimulation. We earnestly thank Professor March for his genuine approach in nurturing future generations of scholars with his curiositydriven and precision-based quest for scholarship. Perhaps this poetry and leadership paper and MOR Award is our best memory dedicated to Professor March, and we truly appreciate his influence on our thinking and writing about ambiguity.

Professor March's insightful and enlightening statement 'ambiguity as source of intelligence' is based on both life and aesthetic experience. The ambiguity in both poetry and leadership provokes imagination and association and brings about artistic fascination. Strongly inspired and encouraged by Professor March, we will carry the baton forward in continuing this unconventional scholarly inquiry of ambiguity while embracing the notion of 'West-Meets-East', and fostering an enhanced understanding of individuals, organizations, and society we live in.

\author{
Yijun Xing ${ }^{1}$ and Yipeng $\mathrm{Liu}^{2}$ \\ ${ }^{1}$ Beijing fiao Tong University, China, and \\ ${ }^{2}$ University of Reading, $U K^{*}$
}

\title{
REFERENGES
}

Coutu, D. 2006. Ideas as art: A conversation with James G. March. Harvard Business Revieze, 84 (10): 82-91.

* This article has been revised since its initial publication. An erratum detailing this change has also been published. See https://doi.org/10.1017/mor.2019.2. 
Cyert, R. M., \& March, J. G. 1963. A behavioral theory of the firm. Englewood Cliffs, NJ: Prentice-Hall.

Lave, G. A., \& March, J. G. 1975. An introduction to models in the social sciences. New York, NY: Harper \& Row.

March, J. G. 1980. Pleasures of the process. London, UK: Poets' and Painters' Press.

March, J. G. 2000. Late harvest. Palo Alto, CA: Bonde Press.

March, J. G. 2006. Poetry and the rhetoric of management: Easter 1916.Journal of Management Inquiry, 15(1): 70-72.

March, J. G. 2010. The ambiguities of experience. Ithaca, NY: Cornell University Press.

March, J. G. 2018. A scholar's quest. Management and Organization Revieze, 14(1): 225-228.

Rhee, M. 2010. The pursuit of shared wisdom in class: When classical Chinese thinkers meet James March. Academy of Management Learning \& Education, 9(2): 258-279.

Xing, Y., \& Liu, Y. 2015. Poetry and leadership in light of ambiguity and logic of appropriateness. Management and Organization Revieze, 11(4): 763-793. 